invisible image on the fovea. Although there is no evidence that this has been a predisposing cause in the writer's case, unless the centrally placed blind patch be so considered, this may be a suitable occasion to issue a caveat to those engaged in occupations involving conditions similar to those described above.

It may be added finally that a complete dental radiological examination and a pathological blood test failed to reveal any contributory abnormalities.

\title{
A CASE OF BILATERAL INTERSTITIAL KERATITIS LEADING TO BLINDNESS
}

BY

\author{
Surg. Lieut.-Comdr. J. D. J. FreEman, R.N.V.R.
}

GLOUCESTER

THIs young stoker completely lost his sight within the space of six months. He was aged nineteen years at the time. There was a "blitz" on Bristol on the night of April 24, 1941, and a bomb fell close to where he was stationed. He did not actually remember anything striking his left eye, but there was a " very bright flash." His head ached after this and during the night his eye became very painful, so that he got very little sleep. The following morning he found his eye was inflamed, he reported at the sick-bay and was admitted to the Naval Hospital at Barrow Gurney the same day.

On admission he was found to have commencing acute interstitial keratitis of his left eye. There was a small epaulette up and out with a "ground glass" area of cornea below. He was treated with atropine and hot bathings and the pupil dilated well. The right eye seemed quite healthy and normal with $6 / 6$ vision. There were no signs of disseminated choroiditis in either eye. The Wassermann reaction of his blood came back as full positive. On May 2 he had to be evacuated to an E.M.S. Hospital, together with most of the other patients in the hospital. He returned to the Naval Hospital on June 10. His left eye was now a shrunken blind eye. There was some panophthalmitis' and the cornea had evidently perforated. While in the E.M.S. Hospital he had had a course of five injęctions of N.A.B. rising from $0.15 \mathrm{gm}$. to $0.60 \mathrm{gm}$. and three injections of Bismuth of $0.2 \mathrm{gm}$. The right eye was-white and the cornea was clear. On July 6 the remains of the left eye were excised under general anaesthesia. The right gave no trouble and was white and free from any inflammation 
until July 14. On this day he complained of pain and photophobia, and on examination was found to have ciliary congestion, and a ground glass patch in the cornea below. He was treated with atropine and hot bathing. The pupil was well dilated but the condition slowly advanced. On July 28 he had well-marked epaulettes above and below. The condition continued to advance and on August 8 the epaulettes were more marked above and below. There was now a mass of K.P. and white necrotic material on Descemet's membrane. As a result of this the iris was not visible. On August 25 he had only P.L. in the eye. The epaulettes had now become confluent and surrounded and diminished the area of the cornea. The cornea was uniformly opaque and the ocular tension was soft. On September 13 he was taken to London and seen in consultation by Sir Arnold Lawson, Consultant Oculist to the Navy. At Sir Arnold Lawson's suggestion, the blood sedimentation rate, complete differential blood count and X-ray of chest were done. These investigations all proved entirely negative. A course of old bovine tuberculin injections was also suggested and given. Prior to this, a course of M. \& B. 693 had been given, followed by Pil Hyd. with Creta grs. 1 t.d.s., and later again Mist. Pot. Iod. grs. 5 t.d.s.- but all without avail. His general condition remained good throughout.

There was no previous history of any eye trouble: His mother and father were alive and well. He was the eldest of five childrentwo brothers and two sisters; none had died. One sister had a discharging ear when a baby and was rather deaf now. Otherwise family history was quite negative. He had had measles, chickenpox and whooping cough and had had his tonsils removed. There was no history of head injury, bed-wetting or sleep walking; no convulsions, fits or faints. He went to an ordinary school until he was fourteen, leaving in the top class. He admitted he was not a good scholar. He was examined by Dr. MacDonald Critchley, Consultant Neurologist to the Navy, on September 19, 1941. He reported that physical examination revealed few signs. The arm jerks were a little brisker on the left side and the right ankle jerk was either very sluggish or absent. There were no stigmata of syphilis with the exception that his teeth were small, widely spaced, possibly peg shaped. At his suggestion a lumbar puncture was done and the cerebro-spinal fluid examined. This revealed no pathological features, and the Wassermann and Lange reactions were negative.

This boy has been granted a full pension and is now at St. Dunstan's, where he is doing very well. This is evidently a case of very severe congenital specific infection of his eyes starting as interstitial keratitis, and going on to bilateral gummatous infiltration of the uveal tract and loss of both eyes. The possibility 
of a superadded tubercular infection was investigated, but no evidence was found of this. An exhaustive search of the literature has failed to reveal the recording of a similar case. For this reason it seemed worth recording this example.

LUMBar Puncture (September 23, 1941)

C.S.F. pressure, 14 Omm. Lab. Report on C.S.F.

$\begin{array}{lcccccl}\text { Cells } & \ldots & \ldots & \ldots & \ldots & \ldots & 26 \text { per mm. } \\ \text { Globulin } & \ldots & \ldots & \ldots & \ldots & \ldots & \text { not increased } \\ \text { Protein } & \ldots & \ldots & \ldots & \ldots & \ldots & 40 \text { mgms. per } 100 \\ \text { Lange } & \ldots & \ldots & \ldots & \ldots & \ldots & 1.2 .3 .4 .2 .1 .1 .0 .0 .0 . \\ \text { W.R. } & \ldots & \ldots & \ldots & \ldots & \ldots & \text { Negative }\end{array}$

Blood Sedimentation Rate (Gibson) September 16, 1941. Normal 94 per cent.

Differential Blood Count (September 16, 19.41)

\begin{tabular}{llllllr} 
Leucocytes & $\ldots$ & $\ldots$ & $\ldots$ & $\ldots$ & $\ldots$ & $8^{\circ} 125$ per c.mm. \\
Polymorphs & $\ldots$ & $\ldots$ & $\ldots$ & $\ldots$ & $\ldots$ & $42^{\circ} 0$ per cent. \\
Lymphocytes $\ldots$ & $\ldots$ & $\ldots$ & $\ldots$ & $\ldots$ & $50^{\circ} 0$ per cent. \\
Monocytes & $\ldots$ & $\ldots$ & $\ldots$ & $\ldots$ & $\ldots$ & $2^{\circ} 0$ per cent. \\
Eosinophils & $\ldots$ & $\ldots$ & $\ldots$ & $\ldots$ & $\ldots$ & $5^{\circ} 0$ per cent. \\
Basophils & $\ldots$ & $\ldots$ & $\ldots$ & $\ldots$ & $\ldots$ & $1^{\circ} 0$ per cent. \\
\multicolumn{5}{c}{ WEIGHT CHART }
\end{tabular}

$\begin{array}{llllllll}\text { June } 6,1941 & \ldots & \ldots & \ldots & \ldots & \ldots & \ldots & 144 \mathrm{lbs} .\end{array}$

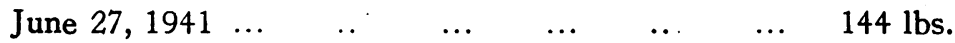
$\begin{array}{llllllll}\text { July } 4,1941 & \ldots & \ldots & \ldots & \ldots & \ldots & \ldots & 140 \text { lbs. }\end{array}$

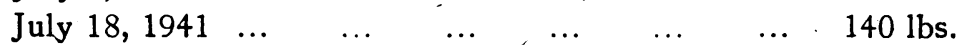
July $25,1941 \ldots \quad \ldots \quad \ldots \quad \ldots . \quad \ldots \quad \ldots \quad 136$ lbs. $\begin{array}{llllllll}\text { August } 1,1941 \quad \ldots & \ldots & \ldots & \ldots & \ldots & 137 \text { lbs. }\end{array}$ $\begin{array}{llllllll}\text { August 18, } 1941 \quad \ldots & \ldots & \ldots & \ldots & \ldots & 140 \text { lbs. }\end{array}$

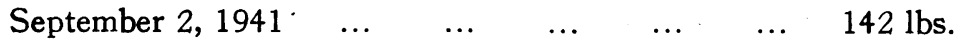

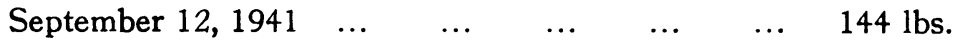
$\begin{array}{llllllll}\text { October } 3,1941 & \ldots & \ldots & \ldots & \ldots & \ldots & \ldots & 154 \text { lbs. }\end{array}$

X-Ray Examination of Chest, September 16, 1941. No abnormality shown. 